\title{
RADIOCARBON DATING OF THE LAST VOLCANIC ERUPTIONS OF CIOMADUL VOLCANO, SOUTHEAST CARPATHIANS, EASTERN-CENTRAL EUROPE
}

\author{
Sz Harangi ${ }^{1,2} \bullet$ M Molnár ${ }^{3}$ A P Vinkler ${ }^{1} \bullet$ B Kiss $^{1} \bullet$ A J T Jull ${ }^{4}$ A G Leonard ${ }^{4}$ \\ ABSTRACT. This paper provides new accelerator mass spectrometry (AMS) radiocarbon age data for the last volcanic \\ events in the Carpathian-Pannonian region of eastern-central Europe. The eruption ages were determined on charcoal frag- \\ ments collected from pumiceous pyroclastic flow deposits at 2 localities of the Ciomadul Volcano. Two charcoal samples \\ from the southeastern margin of the volcano (Bixad locality) set the date of the last volcanic eruption to 27,200 $\pm 260 \mathrm{yr} B P$ \\ $(29,500 \pm 260 \mathrm{cal}$ BC). On the other hand, our data show that the Tusnad pyroclastic flow deposit, previously considered as \\ representing the youngest volcanic rock of the region, erupted at $\sim 39,000 \mathrm{yr} \mathrm{BP}(\sim 41,300 \mathrm{cal} \mathrm{BC})$. Thus, a period of dormancy \\ more than 10,000 yr long might have elapsed between the 2 volcanic events. The different ages of the Tusnad and Bixad pyro- \\ clastic flow deposits are confirmed also by the geochemical data. The bulk pumices, groundmass glass, and the composition \\ of the main mineral phases (plagioclase and amphibole) suggest eruption of slightly different magmas. Considering also the \\ assumed long volcanic history ( $\sim 600 \mathrm{ka}$ ) of the Ciomadul, these data suggest that further detailed studies are necessary on this \\ seemingly inactive volcano in order to evaluate the possible renewal of volcanic activity in the future.
}

\section{INTRODUCTION}

A potentially active volcano is generally considered to be one that erupted in the last $10 \mathrm{ka}$, i.e. during the Holocene (Simkin and Siebert 1984). However, dormant periods between volcanic eruptions could be several tens or hundreds thousand years in certain cases (e.g. Yellowstone; Gansecki et al. 1998; Lanphere et al. 2002). Thus, possible renewal of volcanic activity after a long quiescence period in a seemingly quiet region should be evaluated with great caution. This is mainly due to the different timescales of natural processes and human thought. Classification of volcanoes as to whether they are active or extinct is often controversial (e.g. Szakács et al. 1993), as shown also by the recent example of the unexpected eruption of the Chaitén Volcano after $9000 \mathrm{yr}$ of quiescence (Carn et al. 2009; Lara 2009). Furthermore, our understanding on the activities of volcanoes is still poor. Large caldera systems could be active for millions of years, whereas andesite-dacite composite volcanoes often have a shorter history (usually $<500 \mathrm{ka}$; Simkin and Siebert 1984). In order to better understand the behavior of an apparently inactive volcano and evaluate the possible rejuvenation of the volcanic eruption, it is crucial to constrain the duration of the active and dormant periods and, of course, to know the date of the last eruption.

In the Carpathian-Pannonian region of eastern-central Europe, several volcanic centers have been active during the last $20 \mathrm{Myr}$ (Szabó et al. 1992; Harangi 2001; Seghedi et al. 2005; Pécskay et al. 2006; Harangi and Lenkey 2007). Although they show a decreasing frequency during the Quaternary and no known eruptions have occurred during the Holocene, Szakács et al. (2002) did not exclude the possibility of further volcanic eruptions in the future. The last volcanic eruption in this region took place in the Ciomadul Volcano, SE Carpathians (Juvigne et al. 1994; Moriya et al. 1996; Szakács et al. 2002), which shows a fairly long history of volcanic activity ( $>500$ ka; Szakács et al. 1993). However, the exact age of the latest eruption is not known. This is largely due to the fact that application of conventional dating techniques is problematic for these rocks due to their very mixed character. However, because the pyroclastic flow deposits contain occasional charcoal fragments, radiocarbon dating could be a powerful tool to resolve this question.

\footnotetext{
${ }^{1}$ Department of Petrology and Geochemistry, Eötvös University, 1117 Budapest Pázmány sétány 1/C, Hungary.

${ }^{2}$ Corresponding author. Email: szabolcs.harangi@geology.elte.hu.

${ }^{3}$ Hertelendi Ede Laboratory of Environmental Studies, MTA ATOMKI, Debrecen, Hungary.

${ }^{4}$ NSF Arizona AMS Laboratory, University of Arizona, 1118 East Fourth St, Tucson, Arizona 85721, USA.
}

(C) 2010 by the Arizona Board of Regents on behalf of the University of Arizona Proceedings of the 20th International Radiocarbon Conference, edited by A J T Jull RADIOCARBON, Vol 52, Nr 2-3, 2010, p 1498-1507 
Previously, Juvigne et al. (1994) obtained an age of $10,700 \pm 180 \mathrm{yr}$ BP for the last eruption based on analysis of a piece of charcoal sample from the pyroclastic flow deposit at the Tusnad road cut, at the western margin of the Ciomadul Volcano (Figure 1). Later, Moriya et al. (1995) re-examined this locality and provided a much older age $(>36,770$ and $42,650 \mathrm{yr}$ BP) by dating organic material from the paleosoil underlying the volcanic series. Subsequently, Moriya et al. (1996) were able to analyze another charcoal sample from the upper part of the pyroclastic flow deposit, approximately at the same level where the sample of Juvigne et al. (1994) was collected, and obtained a very similar age as the dated paleosoil ( $>35,670$ and $>35,520 \mathrm{yr}$ BP). Thus, the controversy concerning the age of the last volcanic eruption remains.

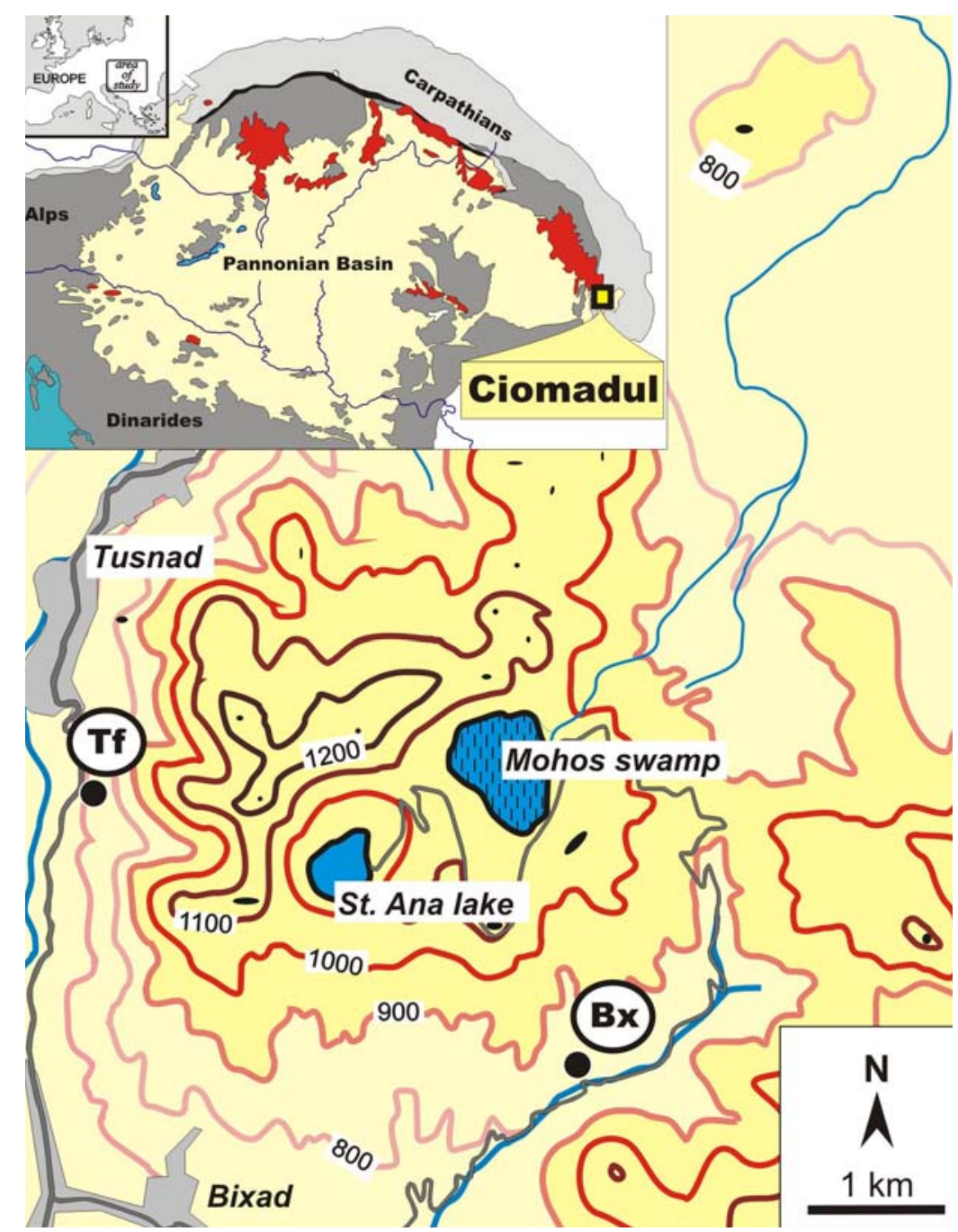

Figure 1 Location of Ciomadul Volcano within Carpathian-Pannonian region and locations of the studied samples within the volcanic complex $(\mathrm{Tf}=$ Tusnad; $\mathrm{Bx}=$ Bixad $)$.

Here, we provide new accelerator mass spectrometry (AMS) ${ }^{14} \mathrm{C}$ age data for the last volcanic event of the Ciomadul Volcano. Based on our results, we point out that the youngest volcanic deposit is found not at Tusnad, as previously generally believed (Juvigne et al. 1994; Moriya et al. 1995, 
1996), but at the southeastern margin of the volcano, where a ${ }^{14} \mathrm{C}$ age of the last volcanic eruption is $27,500 \mathrm{yr}$ BP $(29,500 \mathrm{cal} \mathrm{BC})$. In addition, this eruption was preceded by another significant explosive volcanic event, which resulted in a pyroclastic flow deposit, exposed at Tusnad. The age of this deposit is $\sim 39,000 \mathrm{yr} \mathrm{BP}(41,300 \mathrm{cal} \mathrm{BC})$. The distinct age of these 2 pyroclastic flow deposits is supported also by the different geochemical characteristics of the rocks.

\section{GEOLOGICAL BACKGROUND}

The Ciomadul Volcano is located at the southeasternmost margin of an $~ 100-\mathrm{km}$-long volcanic chain (Calimani-Gurghiu-Harghita Mountains) at the inner foot of the East Carpathians (Figure 1). Remarkably, there is a gradual younging (from 9 to $\sim 0.22 \mathrm{Ma}$ ) of the volcanic activity from north to south (Peltz et al. 1987; Pécskay et al. 1995). The volcanic eruptions resulted in andesitic to dacitic rocks with a typical calc-alkaline character. Within the Harghita Mountains, a sharp change in the composition of the magmas is observed at $\sim 3 \mathrm{Ma}$ (Seghedi et al. 1987; Szakács et al. 1993; Mason et al. 1996). The erupted $<3$-Ma magmas are more potassic and are characterized by different trace element abundances. The Ciomadul Volcano has been built up also by these potassic dacite rocks. Volcanic eruptions started at about $1-0.75 \mathrm{Ma}$, forming sporadic dacitic lava domes, whereas the major lava dome building phase was thought to be at $\sim 650-500 \mathrm{ka}$ based on $\mathrm{K} / \mathrm{Ar}$ radiometric data (Szakács et al. 1993; Pécskay et al. 1995). This volcanism created a lava dome complex. Subsequent explosive eruptions formed 2 explosive craters within it (Mohos and St. Ana). Among them, the St. Ana crater is filled by a lake, which is $6 \mathrm{~m}$ deep and consists of $\sim 12$-m-thick sediments (Magyari et al. 2009). It is surrounded by a crater rim emerging 300-400 $\mathrm{m}$ above the lake level. This crater dimension requires a violent explosive eruption in the past.

The explosive volcanic eruptions formed various pumiceous pyroclastic deposits; however, their outcrops are scarce. The pyroclastic fall beds as well as pyroclastic flow and surge deposits are found mostly around the 2 craters, but also in distal position as far as $25 \mathrm{~km}$ away from the volcano (Moriya et al. 1995; Vinkler et al. 2007). Distinction between the volcanic formations derived from the older Mohos crater and the younger St. Ana crater is difficult both in the field and also based on geochemical data. Conventional dating methods cannot be applied successfully for these rocks because they contain a thoroughly mixed crystal assemblage. In certain rocks, the relative amount of antecrysts and xenocrysts could exceed even $\sim 50$ vol $\%$ of the crystals. These represent either an older crystal mush or are derived from mafic magmas intruded into the dacitic magma chamber (Vinkler et al. 2007; Kiss et al. 2008). All the minerals potentially available for radiometric dating (e.g. zircon, K-feldspar, biotite, and some of the amphiboles) are interpreted as antecryts picked up from an older crystal mush by the fresh dacitic magma. Thus, charcoal samples become very significant in dating the volcanic activities.

Sporadic charcoal fragments have been found in 2 pyroclastic flow deposits at the margins of the Ciomadul Volcano. Massive pyroclastic flow deposits containing pumiceous blocks are exposed along a road cut, south of Tusnad, at the western margin of the volcano (Moriya et al. 1995; Figure 1). It has traditionally been considered as the youngest volcanic rock (Juvigne et al. 1994; Moriya et al. 1995, 1996). Recently, Vinkler et al. (2007) described another locality of pyroclastic flow deposit at the southeastern margin of the volcano, along a road coming from Bixad to the St. Ana crater lake. It is important to note that these are the only detailed studied pyroclastic flow deposits in Ciomadul.

\section{Samples}

Charcoal fragments were found at 2 localities of pyroclastic rocks at Ciomadul Volcano (Tusnad and Bixad). They indicate high temperatures $\left(\sim 300-600^{\circ} \mathrm{C}\right.$; Scott and Glasspool 2005) of the pyroclas- 
tic density currents, sufficient to burn and carbonize woods. Such fragments provide a unique opportunity of dating young ( $<60 \mathrm{ka}$ ) volcanic events (e.g. Orsi et al. 1996; Okuno and Nakamura 2003; Solomina et al. 2008; Zaretskaia et al. 2001). At the Tusnad road cut, a $\sim 10$-m-thick massive pyroclastic flow deposit is found overlaying well-sorted pumiceous pyroclastic fall beds (Moriya et al. 1995; Vinkler et al. 2007). It is a lapilli tuff with occasional pumiceous dacite blocks (Figure 2A). These blocks are crystal-poor and contain dominantly plagioclase and amphibole and less biotite phenocrysts and antecrysts with accessory minerals of apatite, ilmenite, sphene, and zircon. Occasionally, Mg-rich clinopyroxene and orthopyroxene xenocrysts are found in the core of amphibole phenocrysts. Charcoal fragments up to $2 \mathrm{~cm}$ diameter are sporadically found (Figure 2B), mostly in the upper half of the pyroclastic flow deposit. Here, we collected $6 \mathrm{~g}$ of pure charcoal, which we prepared for accelerator mass spectrometry (AMS) ${ }^{14} \mathrm{C}$ dating. The position of this sample is similar to those analyzed by Juvigne et al. (1994) and Moriya et al. (1996). The other outcrop (Bixad) exposes a paleovalley filling pumiceous block-bearing pyroclastic flow deposit (Figure 2C), which contains more abundant and larger charcoal fragments than the Tusnad locality. Charcoal pieces up to $10 \mathrm{~cm}$ long occur mostly at the base of the deposit (Figure 2D). We collected 2 charcoal samples from this locality. The mineral composition of the pumiceous blocks is the same as in the Tusnad locality.

\section{METHODS}

All of our charcoal samples were ${ }^{14} \mathrm{C}$ AMS dated in the NSF Arizona AMS Laboratory. Charcoal is a heterogeneous material, and the removal of contaminating carbon-containing components is a challenging problem during sample preparation for ${ }^{14} \mathrm{C}$ dating (Alon 2002).

Charcoal from geological sites is composed of the charred organic material itself and its diagenetic decomposition products. However, it may also contain associated humic substances (HS) thought to be derived from groundwater, and adhering carbon-containing sediments. For the purposes of ${ }^{14} \mathrm{C}$ dating, the latter 2 components are considered contaminants of the charcoal, as they may contain relatively large amounts of carbon that do not necessarily originate from the same time as the plant material from which the charcoal was derived. Furthermore, the chemical structure of the charcoal itself varies considerably according to the type of burnt material, the conditions of combustion, and the preservation environment following deposition and burial (Guo and Bustin 1998; Nishimiya et al. 1988; Darmstadt et al. 2000).

To solve this problem, we treated the samples first with hydrochloric acid to remove associated carbonates and carbonated apatite, followed by repeated treatments with a dilute solution of sodium hydroxide to remove the humic substances. Finally, the sample is washed again in acid to remove absorbed carbon dioxide, and then dried. This is referred to as the acid-alkali-acid (AAA) procedure (Olson and Broecker 1958; Hatté et al. 2001). The effectiveness of the treatment was evaluated by the absence of color in the extracting alkali solvent solution. Extracted HS from each charcoal samples were precipitated by hydrochloric acid addition and this precipitation was decanted, washed until $\mathrm{pH} \sim 3$, and dried for parallel ${ }^{14} \mathrm{C}$ dating with the charcoals.

In addition, we collected pumices from both localities and analyzed them for bulk rock major and trace element composition as well as for the chemical composition of the main mineral phases (plagioclase and amphibole) and the groundmass glasses. The bulk rock compositions were determined by a PHILIPS PW2400 sequential X-ray spectrometer and ICP-MS methods at the Department of Lithospheric Sciences, University of Vienna, whereas the mineral phases and the groundmass glass were analyzed by a CAMECA SX100 electron-microprobe using $15 \mathrm{kV}$ voltage and $20 \mathrm{nA}$ beam current. For the glasses, we used a defocused beam to minimize the alkali loss. A representative set of geochemical data is found in Vinkler et al. (2007). 
A $\quad$ B
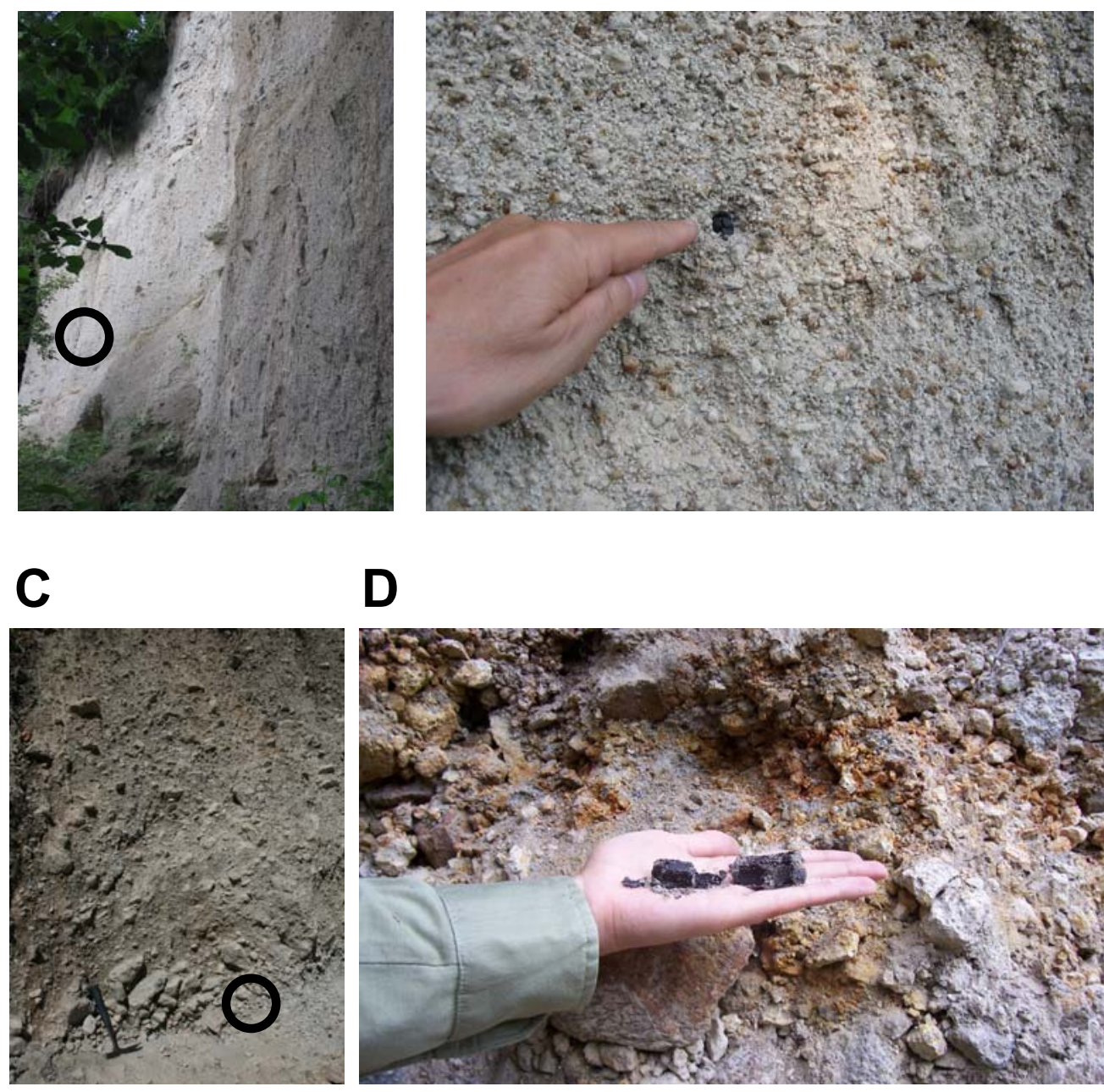

D

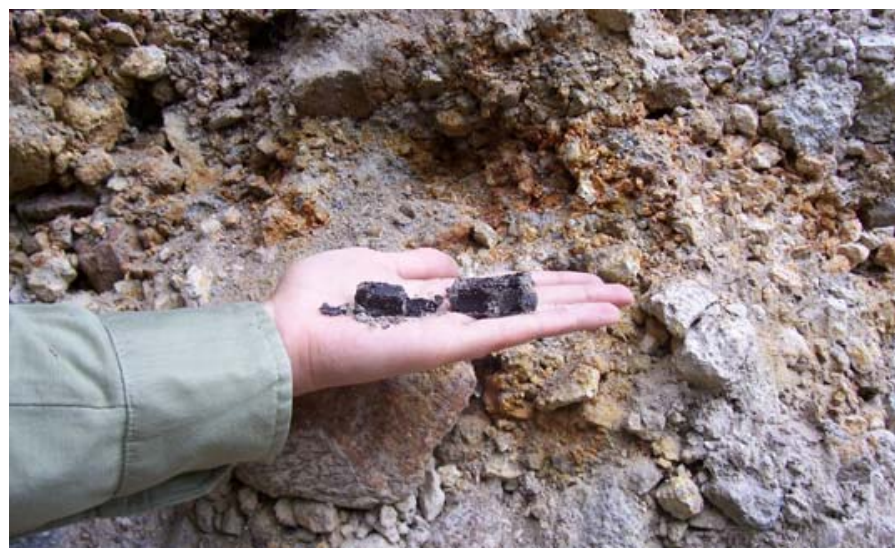

Figure 2 A) Pyroclastic flow deposit at the Tusnad locality with the location of the studied charcoal sample. B) Charcoal sample within the volcanic deposit. C) Pyroclastic flow deposit at the Bixad locality with the location of the studied charcoal sample. D) Charcoal sample from the volcanic deposit.

\section{RESULTS}

\section{Geochemical Compositions}

Both outcrops expose pumiceous pyroclastic deposits, which contain $<5 \%$ of lithic clasts, mostly glassy dacites. We collected sets of pumiceous blocks from different heights of the outcrops. The bulk pumices are potassic dacites with $\mathrm{SiO}_{2}$ ranging from 64 to $67 \mathrm{wt} \%$ and $\mathrm{K}_{2} \mathrm{O}$ content of 3.1-3.5 $\mathrm{wt} \%$. Pumices from the Tusnad locality are usually more silicic than those from the Bixad road cut. This is reflected also in the composition of the glassy groundmass (Figure 3). The pumices contain the same mineral phases; however, their compositions differ significantly. Plagioclases in the Tusnad outcrop usually have a $20-40 \mathrm{~mol} \%$ An component, whereas in the Bixad locality, they are more calcic (An 40-50 mol\%; Figure 3). Amphiboles are usually edenites in the Tusnad pumices, whereas 
in Bixad, pargasites and magnesio-hastingsites are also common. There is a striking difference also in the $\mathrm{Al}_{2} \mathrm{O}_{3}$ content of the amphiboles. The Tusnad amphiboles have $<10 \mathrm{wt} \%$ alumina, whereas the Bixad pumices include more Al-rich amphiboles $\left(\mathrm{Al}_{2} \mathrm{O}_{3}=10-12 \mathrm{wt} \%\right.$; Figure 3).
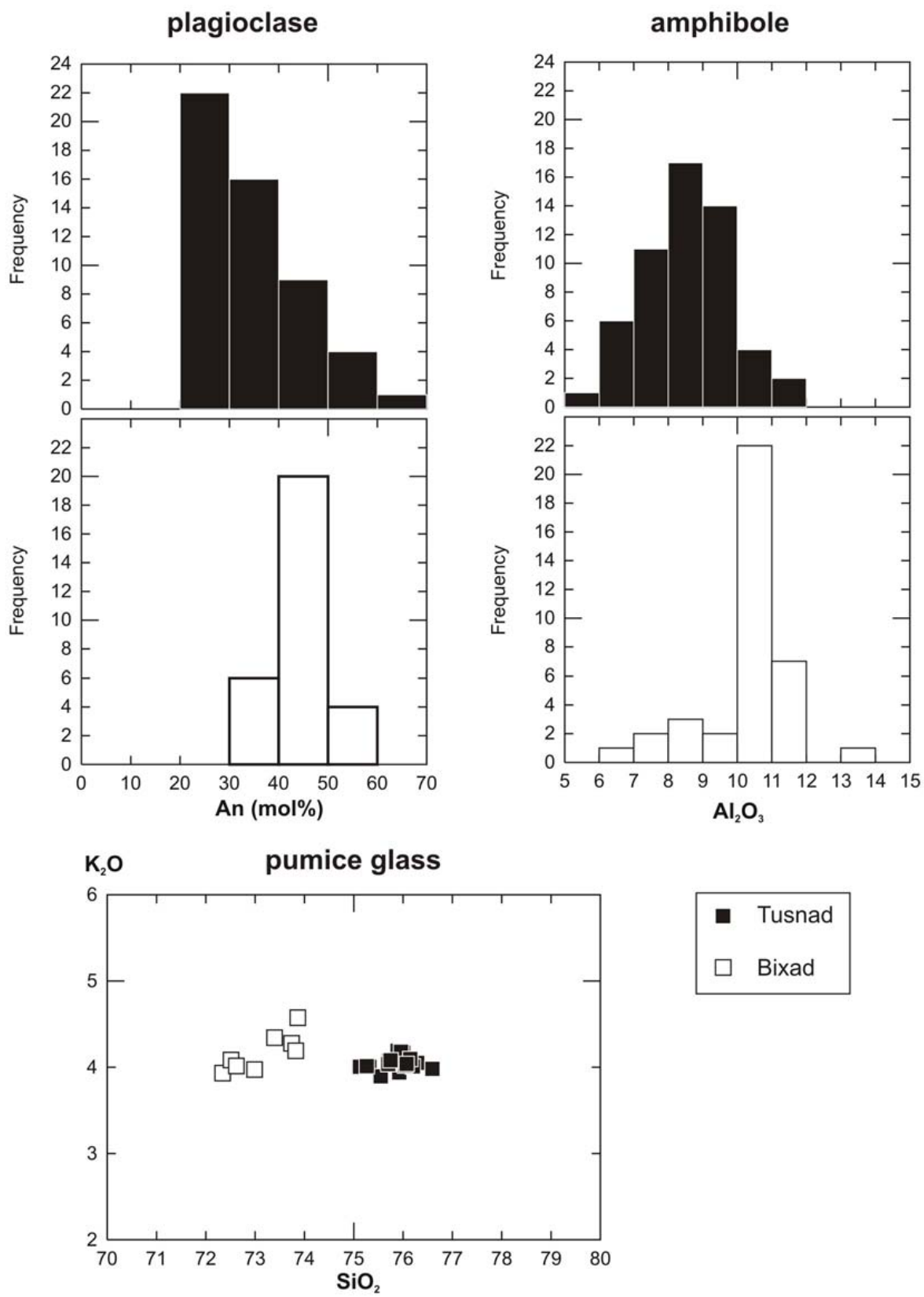

Figure 3 Characteristic geochemical features of the mineral phases (plagioclase and amphibole phenocrysts) and pumice groundmass glass from the 2 pyroclastic deposits of the 2 localities. An $=$ anorthite content $(\mathrm{mol} \%)$ of the plagioclase. 


\section{Radiocarbon Age Data}

${ }^{14} \mathrm{C}$ dating results of charcoal samples are listed in Table 1. Purified pretreated charcoal and their separated humic fractions were also ${ }^{14} \mathrm{C}$ dated. In the case of the Bixad samples (code $\mathrm{Bx}$-), no significant difference was observed between the humin and charcoal ages $(28,000 \mathrm{yr} \mathrm{BP})$ and the stable isotope results obtained. Thus, it could be considered that in the case of Bx samples, the humin fraction originates only from diagenetic decomposition products from the charcoal. On the other hand, we observed significantly older humin relative to its charcoal age in the case of samples from Tusnad (code: TF). Furthermore, the charcoal from Tusnad was also significantly older $(38,700 \pm$ $1000 \mathrm{yr}$ BP) than that from Bixad. For Tusnad samples, during the preparation of humin fraction we had greater problems with samples chemical behavior as they formed stable precipitates only in more acidic conditions ( $\mathrm{pH} \sim 1$ ) than usual. Age calibration was carried out using CALIB Rev 6.0.1 (Reimer et al. 2009; http://intcal.qub.ac.uk/calib/). Thus, the pyroclastic flow deposit at Bixad could have erupted at 29,500 $\pm 260 \mathrm{cal} \mathrm{BC}$, whereas that at Tusnad was formed at about $41,300 \mathrm{cal} \mathrm{BC}$.

Table $1{ }^{14} \mathrm{C}$ results and calibrated ages of the Bixad (Bx) and Tusnad (TF) samples.

\begin{tabular}{lllllll}
\hline Lab code & $\begin{array}{l}\text { Sample } \\
\text { name }\end{array}$ & type & $\begin{array}{l}\delta^{13} \mathrm{C}_{\mathrm{VPDB}} \\
\pm 0.1\end{array}$ & $\begin{array}{l}{ }^{14} \mathrm{C} \text { age } \\
(\mathrm{yr} \text { BP })\end{array}$ & $\begin{array}{l}\text { Calibrated age }^{\mathrm{a}} \\
1 \sigma(\mathrm{cal} \mathrm{BC})\end{array}$ & Method \\
\hline Deb12573 $^{\mathrm{b}}$ & Bx95 & charcoal & $-23.0 \%$ & $27,040 \pm 450$ & $29,710-29,100$ & GPC \\
AA79952 & Bx95 & charcoal & $-22.9 \%$ & $27,200 \pm 260$ & $29,610-29,280$ & AMS \\
AA80170 & Bx95 & humic acid & $-22.9 \%$ & $28,050 \pm 290$ & $30,750-29,820$ & AMS \\
AA79951 & Bx-u & charcoal & $-22.7 \%$ & $27,550 \pm 270$ & $29,990-29,410$ & AMS \\
AA80169 & Bx-u & humic acid & $-23.1 \%$ & $27,910 \pm 280$ & $30,520-29,660$ & AMS \\
AA79953 & TF & charcoal & $-23.8 \%$ & $38,700 \pm 1000$ & $41,900-40,300$ & AMS \\
AA80171 & TF & humic acid & $-23.4 \%$ & $49,000 \pm 3600$ & n/a & AMS \\
\hline
\end{tabular}

${ }^{a}$ Calibrated using CALIB Rev 6.0.1. (Reimer et al. 2009; http://intcal.qub.ac.uk/calib/).

${ }^{b}$ From Vinkler et al. (2007).

\section{DISCUSSION}

New AMS ${ }^{14} \mathrm{C}$ data on charcoal fragments found in pumiceous pyroclastic deposits at 2 localities of the Ciomadul Volcano constrain the age of the last volcanic eruption. These data reveal that the youngest volcanic product is found at the southeastern margin of the volcano, cropping out at the Bixad road cut and not at Tusnad as previously proposed (Juvigne et al. 1994; Moriya et al. 1995, 1996). For the Bixad samples, we obtained consistent ages from 2 charcoal samples that set the date of the last volcanic eruption to $29,500 \pm 260 \mathrm{cal} \mathrm{BC}$. Previous ${ }^{14} \mathrm{C}$ dating on charcoal samples from the Tusnad locality was ambiguous. Our new data $(38,700 \pm 1000 \mathrm{yr}$ BP, i.e. $41,300 \mathrm{cal} \mathrm{BC})$ confirm the older ages obtained by Moriya et al. (1996). The slightly unusual chemical features of humin from the Tusnad sample (described earlier) could have caused problems during sample preparation and could have resulted in the unreliable age obtained by Juvigne et al. (1994).

The distinct ages of the Tusnad and Bixad pyroclastic flow deposits are confirmed also by the geochemical data (Figure 3). The bulk pumices, groundmass glass, and composition of the main mineral phases suggest eruption of slightly different magmas. The explosive eruption resulted in the Tusnad pyroclastic flow was fed by a more evolved magma coming from a shallower depth. The composition of amphiboles and the groundmass glasses indicate about $4 \mathrm{~km}$ depth of the magma chamber for the Tusnad magma, whereas the erupted magma resulted in the Bixad pyroclastic flow could come from about the 5-12 km depth interval. 
The new age data provide additional important information about the temporal evolution of the youngest volcanic activity of Ciomadul. Previously, 2 major explosive eruption events were suggested forming the Mohos and St. Ana craters, respectively (Szakács et al. 1993). The age of the Mohos eruption is unknown, but should be significantly older than that of St Ana. The pyroclastic flow deposits at Tusnad were connected to the St. Ana eruption. Accepting this former conclusion (Szakács et al. 1993), our new data indicate that there were at least 2 major explosive volcanic eruptions from the St. Ana crater with a possible repose time of more than 10,000 yr. This reinforces the unusual behavior of the Ciomadul Volcano, i.e. long quiescent periods could elapse between the active phases. Unfortunately, the lack of suitable mineral phases for radiometric dating in other eruptive products prevents the more refined evaluation of the temporal evolution of the volcano. In this context, the geochemical signatures of the rocks could have significance. The Tusnad rocks appear to have unique mineral chemical composition compared with the lava dome rocks and pyroclastic samples except for the Kövesponk lava dome found in the southern margin of the St. Ana crater. Thus, it could represent eruption of a distinct magma type.

The Ciomadul Volcano has an unusual character. Although it is a low-productive volcano, it has a relatively long eruptive history. A single $\mathrm{K} / \mathrm{Ar}$ radiometric age date indicates that the Mohos crater could have been active at $\sim 220 \mathrm{ka}$, whereas the active lava dome-building phase was at about 650 500 ka (Szakács et al. 1993; Pécskay et al. 1995). Thus, even a longer repose time might have occurred during the past. These data, along with our new ${ }^{14} \mathrm{C}$ data, suggest the importance of careful investigation of seemingly quiet volcanoes, which show long dormant periods between active phases. In this context, we cannot consider unambiguously the Ciomadul Volcano as an inactive volcano, and further investigations are necessary to get a more refined data for its temporal evolution.

\section{CONCLUSIONS}

The new ${ }^{14} \mathrm{C}$ data provided valuable information on the behavior of the Ciomadul Volcano and help to constrain the time of its last eruption The main conclusions are the following:

1. The last volcanic eruption occurred at about $27,500 \mathrm{yr}$ BP (i.e. 29,500 cal BC).

2. The product of the youngest eruption is exposed at the southeastern margin of the volcano (Bixad locality) and not at the western one (Tusnad locality) as was previously thought. Our new data confirms the age for the Tusnad pyroclastic flow provided by Moriya et al. (1996). The Tusnad pyroclastic flow erupted 41,300 cal BC.

3. A striking new result is that there were at least 2 major explosive eruptions, not a single one, related to the formation of the St. Ana crater. This is supported also by the geochemical data of the pumices and the main mineral phases. The youngest eruption could have occurred after a quiescence period of possibly more than $10 \mathrm{ka}$.

4. Further dating for the time of the older eruptions is crucial to understand the nature of the volcano and to evaluate the characteristic repose time of Ciomadul. A zircon dating is in progress that could constrain also the residence time of the magma reservoirs.

\section{ACKNOWLEDGMENTS}

This research on the Ciomadul Volcano belongs to the scientific project supported by the OTKA (Hungarian National Research Fund) No. K68587. The work at the University of Arizona was supported in part by NSF grant EAR06-22305. Constructive reviews and critical remarks provided by Guido Giordano and an anonymous reviewer are acknowledged. 


\section{REFERENCES}

Alon D, Mintz G, Cohen I, Weiner S, Boaretto E. 2002. The use of Raman spectroscopy to monitor the removal of humic substances from charcoal: quality control for ${ }^{14} \mathrm{C}$ dating of charcoal. Radiocarbon 44(1): $1-11$.

Carn SA, Pallister JS, Lara L, Ewert JW, Watt S, Prata AJ, Thomas RJ, Villarosa G. 2009. The unexpected awakening of Chaitén Volcano, Chile. Eos, Transactions American Geophysical Union 90(24):205, doi: 10.1029/2009EO240001.

Darmstadt H, Pentea D, Sümmchen L, Roland U, Kaliaguine S, Roy C. 2000. Surface and bulk chemistry of charcoal obtained by vacuum pyrolysis of bark: influence of feedstock moisture content. Journal of Analytical and Applied Pyrolysis 53(1):1-17.

Gansecki CA, Mahood GA, McWilliams M. 1998. New ages for the climactic eruptions at Yellowstone: single-crystal ${ }^{40} \mathrm{Ar} /{ }^{39} \mathrm{Ar}$ dating identifies contamination. Geology 26(4):343-6.

Guo Y, Bustin RM. 1988. FTIR spectroscopy and reflectance of modern charcoal and fungal decayed wood: implications for studies of inertinite in coals. International Journal of Coal Geology 37(1-2):29-53.

Harangi S. 2001. Neogene to Quaternary volcanism of the Carpathian-Pannonian region - a review. Acta Geologica Hungarica 44:223-58.

Harangi S, Lenkey L. 2007. Genesis of the Neogene to Quaternary volcanism in the Carpathian-Pannonian region: role of subduction, extension, and mantle plume. GSA Special Papers 418. p 67-92.

Hatté C, Morvan J, Noury C, Paterne M. 2001. Is classical acid-alkali-acid treatment responsible for contamination? An alternative proposition. Radiocarbon 43(2A): 177-82.

Juvigne E, Gewelt M, Gilot E, Hurtgen C, Seghedi I, Szakács A, Gábris G, Hadnagy Á, Horváth E. 1994. Une eruption vieille d'environ 10700 ans $\left({ }^{14} \mathrm{C}\right)$ dans les Carpates orientales (Roumanie). Comptes Rendus de l'Académie des Sciences 318:1233-8.

Kiss B, Harangi S, Vinkler AP, Ntaflos T, Mason PRD. 2008. Magma evolution and magma ascent rate beneath Ciomadul, the youngest volcano in the Carpathian-Pannonian region. Geophysical Research $A b$ stracts 10: EGU2008-A-11292.

Lanphere MA, Champion DE, Christiansen RL, Izett GA, Obradovich JD. 2002. Revised ages for tuffs of the Yellowstone Plateau volcanic field: assignment of the Huckleberry Ridge Tuff to a new geomagnetic polarity event. Geological Society of America Bulletin 114(5):559-68.

Lara LE. 2009. The 2008 eruption of the Chaitén Volcano, Chile: a preliminary report. Andean Geology $36(1): 125-9$

Magyari E, Buczkó K, Jakab G, Braun M, Pál Z, Karátson D, Pap I. 2009. Palaeolimnology of the last crater lake in the Eastern Carpathian Mountains: a multiproxy study of Holocene hydrological changes. Hydrobiologia 631(1):29-63.

Mason PRD, Downes H, Thirlwall M, Seghedi I, Szakács A, Lowry D, Mattey D. 1996. Crustal assimilation as a major petrogenetic process in the east Carpathian Neogene and Quaternary continental margin arc, Romania. Journal of Petrology 37(4):927-59.

Moriya I, Okuno M, Nakamura E, Szakács A, Seghedi I. 1995. Last eruption and its ${ }^{14} \mathrm{C}$ age of Ciomadul Volcano, Romania. Summaries of Researches Using AMS at Nagoya University 6:82-91.

Moriya I, Okuno M, Nakamura T, Ono K, Seghedi I. 1996. Radiocarbon ages of charcoal fragments from the pumice flow deposits of the last eruption of Ciomadul Volcano, Romania. Summaries of Researches Using AMS at Nagoya University (VII) 3:252-5.

Nishimaya K, Hata T, Imamura Y, Ishihara S. 1998. Analysis of chemical structure of wood charcoal by Xray photoelectron spectroscopy. Journal of Wood Science 44(1):56-61.

Okuno M, Nakamura T. 2003. Radiocarbon dating of tephra layers: recent progress in Japan. Quaternary International 105(1):49-56.

Olson EA, Broecker WS. 1958. Sample contamination and reliability of radiocarbon dates. Transactions of the New York Academy Sciences Series II 20:593-604.

Orsi G, Piochi M, Campajola L, D’Onofrio A, Gialanella L, Terrasi F. 1996. ${ }^{14} \mathrm{C}$ geochronological constraints for the volcanic history of the island of Ischia (Italy) over the last 5000 years. Journal of Volcanology and Geothermal Research 71(2-4):249-57.

Pécskay Z, Edelstein O, Seghedi I, Szakács A, Kovacs M, Crihan M, Bernad A. 1995. K-Ar datings of Neogene-Quaternary calc-alkaline volcanic rocks in RoMania. In: Downes H, Vaselli O, editors. Neogene and Related Magmatism in the Carpatho-Pannonian Region. Acta Vulcanologica 7:53-61.

Pécskay Z, Lexa L, Szakács A, Seghedi I, Balogh K, Konecny V, Zelenka T, Kovacs M, Póka T, Fülöp A, Márton E, Panaiotu C, Cvetkovic V. 2006. Geochronology of Neogene magmatism in the Carpathian arc and intra-Carpathian area. Geologica Carpathica 57: $511-30$.

Peltz S, Vajdea E, Balogh K, Pécskay Z. 1987. Contributions to the chronological study of the volcanic processes in the Calimani and Harghita Mountains (East Carpathians, Romania). Dari de Seama ale Sedintelor Institutul de Geologie si Geofizica 72-73:323-38.

Reimer PJ, Baillie MGL, Bard E, Bayliss A, Beck JW, Blackwell PG, Bronk Ramsey C, Buck CE, Burr GS, Edwards RL, Friedrich M, Grootes PM, Guilderson TP, Hajdas I, Heaton TJ, Hogg AG, Hughen KA, Kaiser KF, Kromer B, McCormac FG, Manning SW, Reimer RW, Richards DA, Southon JR, Talamo S, Turney CSM, van der Plicht J, Weyhenmeyer CE. IntCa109 and Marine09 radiocarbon age calibration 
curves, 0-50,000 years cal BP. Radiocarbon 51(4): 1111-50.

Scott AC, Glasspool IJ. 2005. Charcoal reflectance as a proxy for the emplacement temperature of pyroclastic flow deposits. Geology 33(7):589-92.

Seghedi I, Szakács A, Udrescu C, Stoian M, Grabari G. 1987. Trace elements geochemistry of the South Harghita volcanics (East Carpathians): calc-alkaline and shoshonitic association. Dari de Seama ale Sedintelor Institutul de Geologie si Geofizica 72-73:38197.

Seghedi I, Downes H, Harangi S, Mason PRD, Pecskay Z. 2005. Geochemical response of magmas to Neogene-Quaternary continental collision in the Carpathian-Pannonian region: a review. Tectonophysics 410(1-4):485-99.

Simkin T, Siebert L. 1984. Explosive eruptions in space and time: durations, intervals, and a comparison of the world's active volcanic belts. In: Explosive Volcanism: Inception, Evolution, and Hazards. Washington, DC: National Academy Press. p 110-21.

Solomina O, Pavlova I, Curtis A, Jacoby G, Ponomareva V, Pevzner M. 2008. Constraining recent Shiveluch Volcano eruptions (Kamchatka, Russia) by means of dendrochronology. Natural Hazards and Earth System Sciences 8(5):1083-97.
Szabó C, Harangi S, Csontos L. 1992. Review of Neogene and Quaternary volcanism of the CarpathianPannonian region. Tectonophysics 208(1-3):243-56.

Szakács A, Seghedi I, Pécskay Z. 1993. Pecularities of South Hargitha Mts. as the terminal segment of the Carpathian Neogene to Quaternary volcanic chain. Revue Roumaine de Géologie Géophysique et Géographie, Géologie 37:21-37.

Szakács A, Seghedi I, Pécskay Z. 2002. The most recent volcanism in the Carpathian-Pannonian Region. Is there any volcanic hazard? Geologica Carpathica Special Issue, Proceedings of the XVIIth Congress of Carpathian-Balkan Geological Association 53:1934.

Vinkler AP, Harangi S, Ntaflos T, Szakács A 2007. A Csomád vulkán (Keleti Kárpátok) horzsaköveinek kozettani és geokémiai vizsgálata: petrogenetikai következtetések. (Petrology and geochemistry of the pumices from the Ciomadul Volcano (Eastern Carpathians) - implications for the petrogenetic processes). Földtani Közlöny 137:103-28.

Zaretskaia NE, Ponomareva VV, Sulerzhitsky LD, Dirksen OV. 2001. Radiocarbon dating of the Kurile Lake caldera eruption (South Kamchatka, Russia). Geochronometria 20:95-102. 